\title{
THE EFFECTS OF CABLE CHARACTERISTICS ON MAXIMUM OVERVOLTAGE IN COMBINED OVERHEAD/CABLE LINES PROTECTED BY SURGE ARRESTERS
}

\author{
Reza AlizadeH* and MoHAmMad Mirzaie \\ Department of Electrical and Computer Engineering, Babol Noshirvani University of \\ Technology, Shariati Ave, Babol, Iran. \\ ${ }^{*}$ Corresponding author: reza.alizadeh14@gmail.com \\ (Received: $7^{\text {th }}$ Aug 2016; Accepted: $7^{\text {th }}$ Feb 2017; Published on-line: $1^{\text {st }}$ June 2018) \\ https://doi.org/10.31436/iiumej.v19i1.707
}

\begin{abstract}
This paper presents the calculation of maximum lightning overvoltage for a transmission system consisting of overhead lines in combination with an underground power cable. For this purpose, a $132 \mathrm{kV}$ overhead transmission line combined with an underground cable is considered. This combined line has been protected by surge arresters. EMTP-RV and MATLAB software are used to conduct the modeling, simulation and calculation works. Lightning strikes on the tower top and results in large over-voltages appearing along overhead lines and cable. Underground cable characteristics have significant effects on maximum lightning over-voltages. Therefore, the three characteristics considered for these effects are: (i) cable length; (ii) cable core resistivity, (iii) cable sheath resistivity. Tower footing resistance effect is also included in the computer simulation.
\end{abstract}

ABSTRAK: Kajian ini berkenaan tentang pengiraan takat maksimum voltan kilat berlebihan bagi sistem transmisi melibatkan kabel atas kepala termasuk kabel tenaga bawah tanah. Bagi tujuan ini, talian kabel penghantaran atas kepala $132 \mathrm{kV}$ termasuk kabel bawah tanah telah diambil kira. Kombinasi kabel ini dilindungi dengan penahan lonjakan voltan tenaga. Perisian EMTP-RV dan MATLAB telah digunakan untuk membuat model, simulasi dan kerja-kerja pengiraan. Panahan petir di atas puncak bangunan merupakan penyebab utama voltan berlebihan muncul bersama talian atas kepala dan kabel. Ciri-ciri kabel bawah tanah merupakan faktor penyumbang utama ke atas voltan berlebihan daripada kilat. Oleh itu, tiga kes telah diambil kira sebagai penyumbang voltan berlebihan: (i) panjang kabel; (ii) rintangan teras kabel, (iii) rintangan sarung kabel. Kesan rintangan tapak bangunan turut diambil kira dalam simulasi komputer.

KEYWORDS: combined line; overvoltage; surge arrester; cable; lightning

\section{INTRODUCTION}

Overhead lines are important parts of power networks. They transfer electrical energy from the point of generation to the place of consumption. The coexistence of overhead and cable lines in the so called "combined" lines raises several questions regarding their behavior both in steady state and in transient. In recent years, with the expansion of the power system and increasing demand for power, cable lines and combined overhead 
transmission lines with underground power cables have been used. Cable lines offer the possibility of a reduced environmental impact; for this reason they are often accepted by public opinion instead of new overhead lines. Nowadays, cross-linked polyethylene cables (XLPE) are the most common cable types in underground cable systems and power transmission networks. A fault in the cable system can lead to an outage of equipment from electric networks [1] because the insulation of underground insulated cables is not self-restoring such as air insulated transmission lines where the basic insulation level (BIL) may decrease as a result of aging. Furthermore, repairing damaged cable lines takes several days or even weeks [2]. Therefore, protection of cables in combined transmission lines is very important. There is a very obvious difference in the risk and magnitude of any lightning impulse in an underground cable compared to that on an overhead line. Power cables are designed according to the required transient impulse and power frequency voltage withstand levels. Transient faults are typically caused by lightning activity, and they have a very short duration. Thus, lightning overvoltages must be taken into account in the insulation system designing process because it can be a major cause for underground cable failure [3-4]. This problem has recently been analyzed by a CIGRE WG (B1.05) [5]. As noted above, lightning impulse voltage is the main parameter in the design of insulation that is defined in an IEEE standard as $1.2 / 50 \mu$ s impulse voltage [6]. When a lightning strike hits a conductor line or the inside of an overhead line in a transmission network, two travelling waves are set up and spread quickly. Once the wave, which travels to the underground cable, meets the arrester, both reflected and refracted waves are initiated. Over time, gradually decreased electrical resistance of the cable insulation and low amplitude overvoltage can lead to cable insulation failure [7]. Cable line length has a significant effect on the amount of maximum overvoltage along a cable. Therefore, surge arresters can be used to decrease faults and overvoltage in cable lines [8]. Surge arresters have high impedance against normal voltage and have low impedance against transient voltages, thereby transferring those electric waves to the ground. Reference [9] attempts to assess the reliability of three common substation configurations. At first, maximum voltages on equipment are calculated in different lightning strike locations through simulation in EMTP-RV. Then the impact of the surge arrester placement on substations reliability indices is calculated. Reference [3] describes the maximum over voltage in a cable protected by surge arresters at both ends due to a continuous reflected voltage wave between cable ends that had occurred within the cable but not in the terminals. In this case, the shorter the length of cable, the higher the maximum overvoltage will be. Hence, cable line length has an important role in insulation coordination [10-11]. Reference [12] presents an improved approach where the JMARTI line model is utilized to obtain voltages and currents at the line ends used to calculate the internal points using an off-line time step. The analysis of maximum overvoltages inside an underground cable due to lightning strokes is presented in [8] based on lattice diagrams. However, according to this reference, proper attenuation constants are not accounted for, yielding approximate positions where the maximum voltage occurs. A frequency-domain (FD) approach has been presented to calculate the maximum overvoltage along an underground cable due to lightning [13]. It is considered that the underground cable is protected by surge arresters at both ends. In this proposed method, the cable is spatially subdivided and direct FD algebraic relations are used to calculate the voltage at each subdivision. In this reference, surge arresters are piece-wise represented in the FD and resolved based on the superposition principle. Flashovers are also assessed and resolved in the FD using the superposition principle. Reference [14] deals with frequency-dependent surge arrester models and transmission line models utilized for insulation coordination studies. In this 
paper, various frequency-dependent surge arrester models and transmission line models have been compared. Simulations of lightning transients in the analyzed power system have been performed and presented for various surge arrester and overhead line models. Also, influence of models application during calculations on simulation results has been analyzed.

In this paper, maximum overvoltage along the cable is calculated by adding the peak value of the voltage wave in the forward direction and the peak value of the voltage wave in the backward direction. This sum is greater than the voltage at the remote end when the two maxima do not appear simultaneously. This paper is aimed at determining the effect of cable and tower characteristics on maximum lightning overvoltage in combined overhead/cable lines, which is explained in different sections. These characteristics are cable length, cable core resistivity, cable sheath resistivity and tower footing resistance.

\section{THEORY OF DETERMINE THE MAXIMUM OVERVOLTAGE}

Figure 1 shows an overview of the under studied system and cable status. The lengths of the overhead lines on both sides of the cable are to be assumed infinite and the cable is also protected by surge arresters at both ends. The aim is to calculate the maximum overvoltage along the cable caused by lightning strikes on the overhead line.

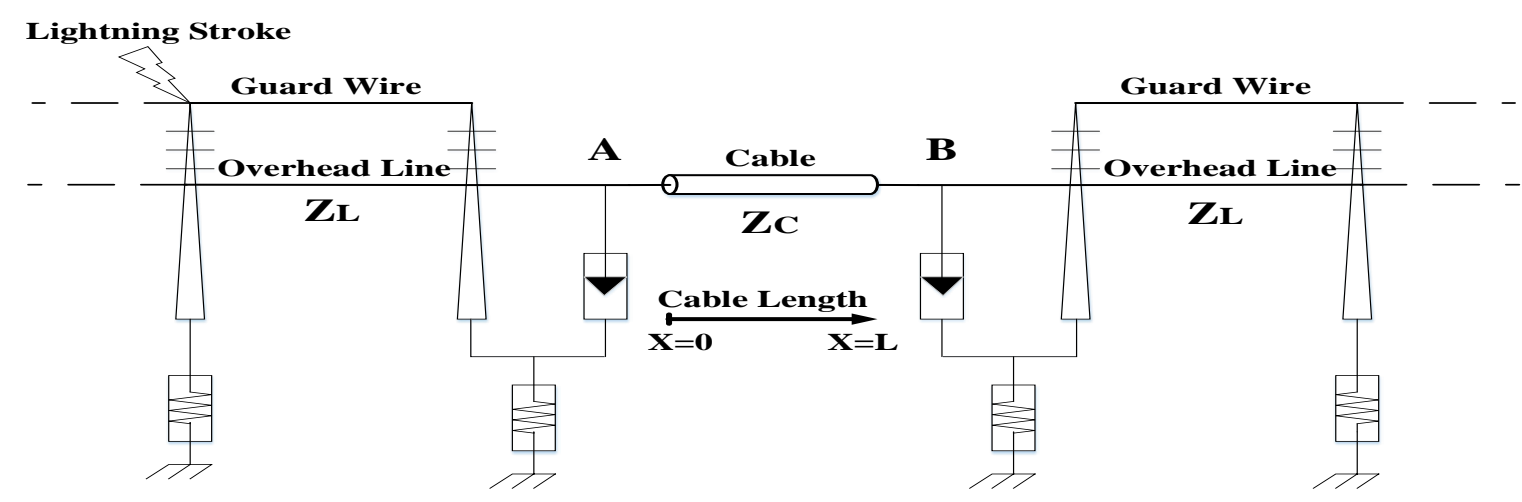

Fig. 1: Combined transmission line.

The voltage at any point $\mathrm{x}$ along the cable is calculated by the sum of a forward voltage $(+)$ and a backward voltage (-) propagating wave [3].

$$
V(x, t)=V_{+}(x, t)+V_{-}(x, t)
$$

Where the forward voltage wave $\left(V_{+}\right)$is generated at the exposed end $(x=0)$ and the backward wave $\left(V_{-}\right)$generated at the remote end $(\mathrm{x}=\mathrm{L})$ [3].

$$
i_{\text {arr }}(t)=\frac{2 \times V_{+}(L, t)}{Z_{C}}-\frac{V(L, t)}{Z_{C}}+\frac{V(L, t)}{Z_{L}}
$$

Where $Z_{C}$ and $Z_{L}$ are the characteristic impedance of the cable and overhead line, respectively. These characteristic impedances are determined by EMTP-RV. Then, according to equations 1 and 2, forward and backward waves are calculated by the following equations:

$$
V_{+}(L, t)=\left(\frac{Z_{C}}{2}\right) i_{\text {arr }}(t)+\left(\frac{Z_{C}+Z_{L}}{2 Z_{L}}\right) V(L, t)
$$


$V_{-}(L, t)=V(L, t)-V_{+}(L, t)$

Generally, the flowchart of calculating maximum overvoltage along a cable has been found in Fig. 2.

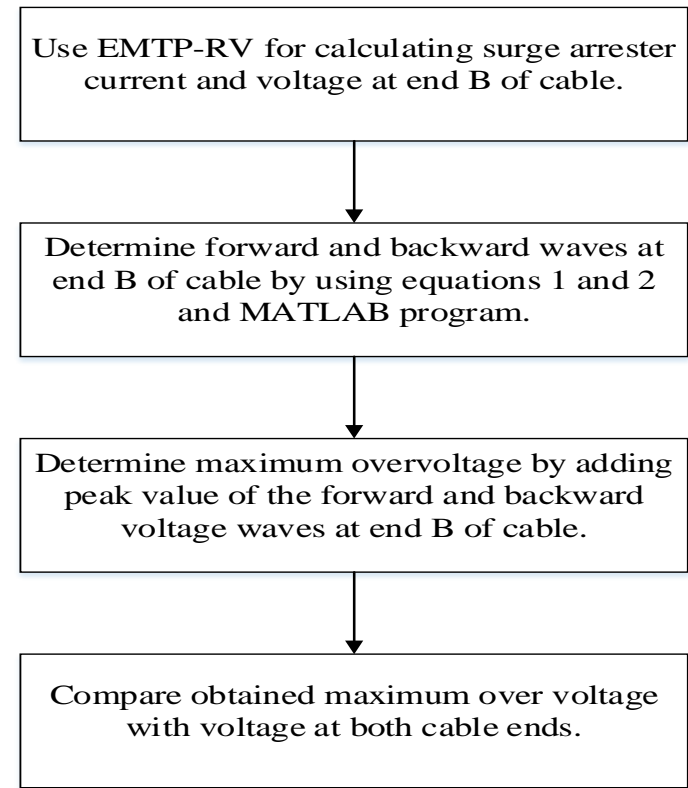

Fig. 2: Flowchart for determining maximum overvoltage along the cable.

\section{DESCRIPTION OF THE NETWORK CONFIGURATION AND MODEL}

In this paper, a three phase combined transmission line (consists of overhead lines and cable lines) is selected to determine the maximum lightning overvoltage at one phase of the network. This system is simulated in EMTP-RV software. In this system, voltage and frequency are $132 \mathrm{kV}$ and $50 \mathrm{~Hz}$, respectively. Overhead line length at both ends of the cable is infinite; and span lengths of overhead line are assumed to be $200 \mathrm{~m}$ cables per phase, protected by surge arresters at both ends. Figure 3 shows the basic configuration for one phase.

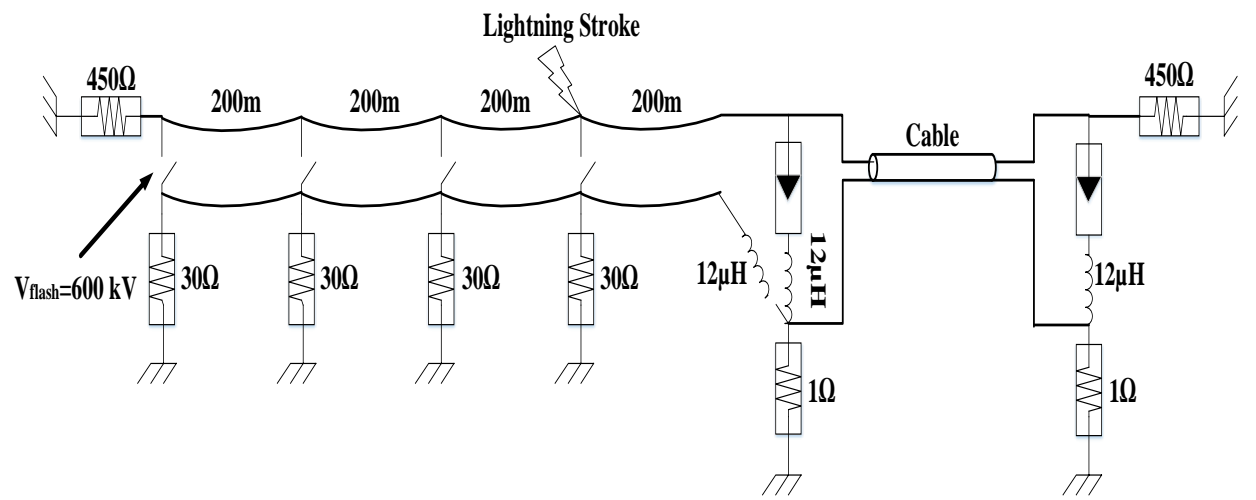

Fig. 3: System basic configuration.

The steel towers are usually represented as a single conductor distributed parameter line terminated by a resistance representing the tower footing impedance [15]. It has been known that the footing impedance tends to be capacitive in the case of a high resistivity 
earth, and inductive in low-resistivity earth. It can be resistive, inductive, and capacitive depending on the season and the weather. Therefore, footing impedance is modeled by resistance [16]. A constant parameter (CP) model is used to simulate the towers. Tower surge impedance and wave velocity, as the principal parameters of the CP line, are considered to be $200 \Omega$ and $3 \times 10^{8} \mathrm{~m} / \mathrm{s}$, respectively. The footing resistance is considered $30 \Omega$.

The lightning surge is modeled by a current and a parallel resistance (Cigre model). This resistance value is assumed to be $400 \Omega$, which was derived by Bewley [16]. In this paper, lightning current is considered to be $200 \mathrm{kA}$ with $1 \mu$ s front time and $300 \mu$ s time to half value strikes the tower top in the second tower. This causes a back-flashover in the struck tower. A flashover is assumed to take place at the second tower, when the magnitude of the voltage between the phase conductor and the tower exceeds $600 \mathrm{kV}$. Note that no flashover occurs in the right part of the line; and ground wires are neglected in that part of the line.

Also, in this paper, a frequency-dependent model (FD model) is used for overhead lines. In this model, resistance and inductance of the transmission line are considered as an FD model determined by skin and ground effects. Line capacitance is assumed constant and a non-zero parallel conductance included in this model. Table 1 and Table 2 show technical specifications of transmission line consisting of conductors and guard wires and Table 4 shows input data for conductor and guard wires.

Table 1: Technical specifications of conductors

\begin{tabular}{cccc}
\hline Conductor number & Phase & Horizontal distance (m) & Vertical distance (m) \\
\hline 1 & 1 & -4.15 & 23.2 \\
2 & 2 & -4.15 & 19.2 \\
3 & 3 & -4.15 & 15.2 \\
4 & 4 & 4.15 & 23.2 \\
5 & 5 & 4.15 & 19.2 \\
6 & 6 & 4.15 & 15.2 \\
\hline
\end{tabular}

Table 2: Technical specifications of guard wires

\begin{tabular}{ccc}
\hline Guard wire number & Horizontal distance (m) & Vertical distance (m) \\
\hline 1 & -4.15 & 26.5 \\
2 & 4.15 & 26.5 \\
\hline
\end{tabular}

The studied cable is XLPE, single core with $630 \mathrm{~mm}^{2}$ cross section. Figure 4 indicates diagrammatic representation of the cylindrical cable in EMTP-RV. Table 3 presents the input data of the cable in EMTP-RV. Six single-core cables deployed in a triangle, like in Fig. 5 are located underground. This type of configuration is common between conductors, because of the reduction of the magnetic coupling effect and it is preferable to bury it flat. Table 5 shows the amount of peculiarity phases. Horizontal axis (X) is parallel with the ground and vertical axis (Y) is perpendicular to the ground. The origin of the coordinates 
is the intersection of the vertical axis that passes from center of the cable 1 to the ground surface. In this paper, ground resistivity is considered $100 \Omega$.

Table 3: Technical data for cable

\begin{tabular}{ccccc}
\hline Cable layers & $\begin{array}{c}\text { Outer radius } \\
{[\mathbf{m}]}\end{array}$ & $\begin{array}{c}\text { Resistivity } \\
\text { [ohm-m] }\end{array}$ & $\begin{array}{c}\text { Relative } \\
\text { permittivity }\end{array}$ & $\begin{array}{c}\text { Relative } \\
\text { permeability }\end{array}$ \\
\hline Conductor & 0.01525 & $1.946 \mathrm{E}-8$ & - & 1 \\
$\begin{array}{c}\text { Internal } \\
\text { insulation }\end{array}$ & 0.03725 & - & 3.052 & 1 \\
$\begin{array}{c}\text { Sheath } \\
\text { External }\end{array}$ & 0.038087 & $1.678 \mathrm{E}-8$ & - & 1 \\
insulation & 0.043087 & - & 3.125 & 1 \\
\hline
\end{tabular}

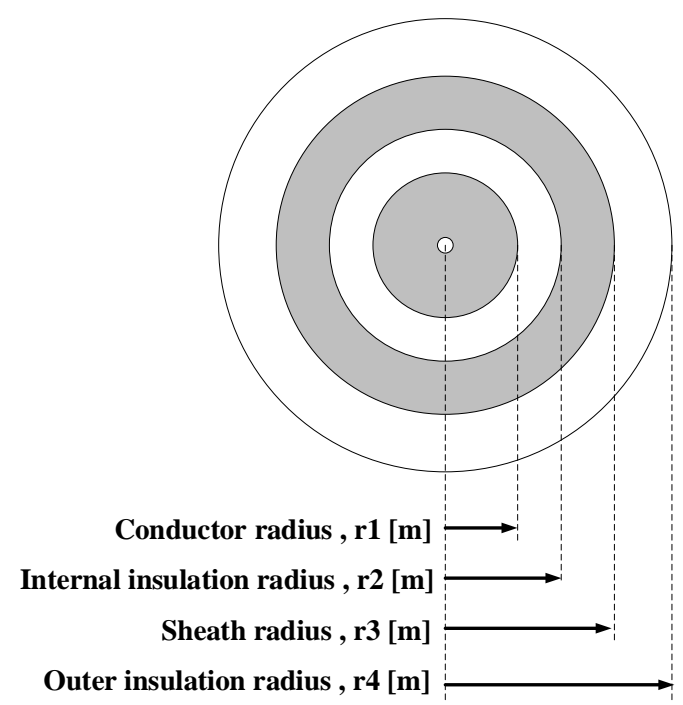

Fig. 4: Diagrammatic representation of underground cable in EMTP-RV.

Table 4: Technical data for the conductor and guard wire

\begin{tabular}{cc}
\hline Characteristics & Input data \\
\hline Conductor name & Moose/olive \\
Number of conductors & 6 \\
Conductors radius [m] & 0.013 \\
DC resistance of the conductor [ohm/km] & 0.1 \\
Vertical height at midspan for conductors [m] & 5 \\
Guard wire name & opal \\
Number of guard wires & 2 \\
Guard wire radius [m] & 0.00653 \\
DC resistance of the guard wire [ohm/m] & 2.9 \\
Vertical height at midspan for guard wires [m] & 5 \\
\hline
\end{tabular}


The voltage reference is $132 \times \sqrt{2 / 3}=107.8 \mathrm{kV}$, which equals to 1 P.U. A protective level and per unit reference voltage and inductance of the surge arrester are considered to be $395 \mathrm{kV}$ and $12 \mu \mathrm{H}$, respectively. The common grounding resistance for the cable screen, the arrester, and the adjacent tower is $1 \Omega$. The surge arrester V-I characteristic is given in Table 6.

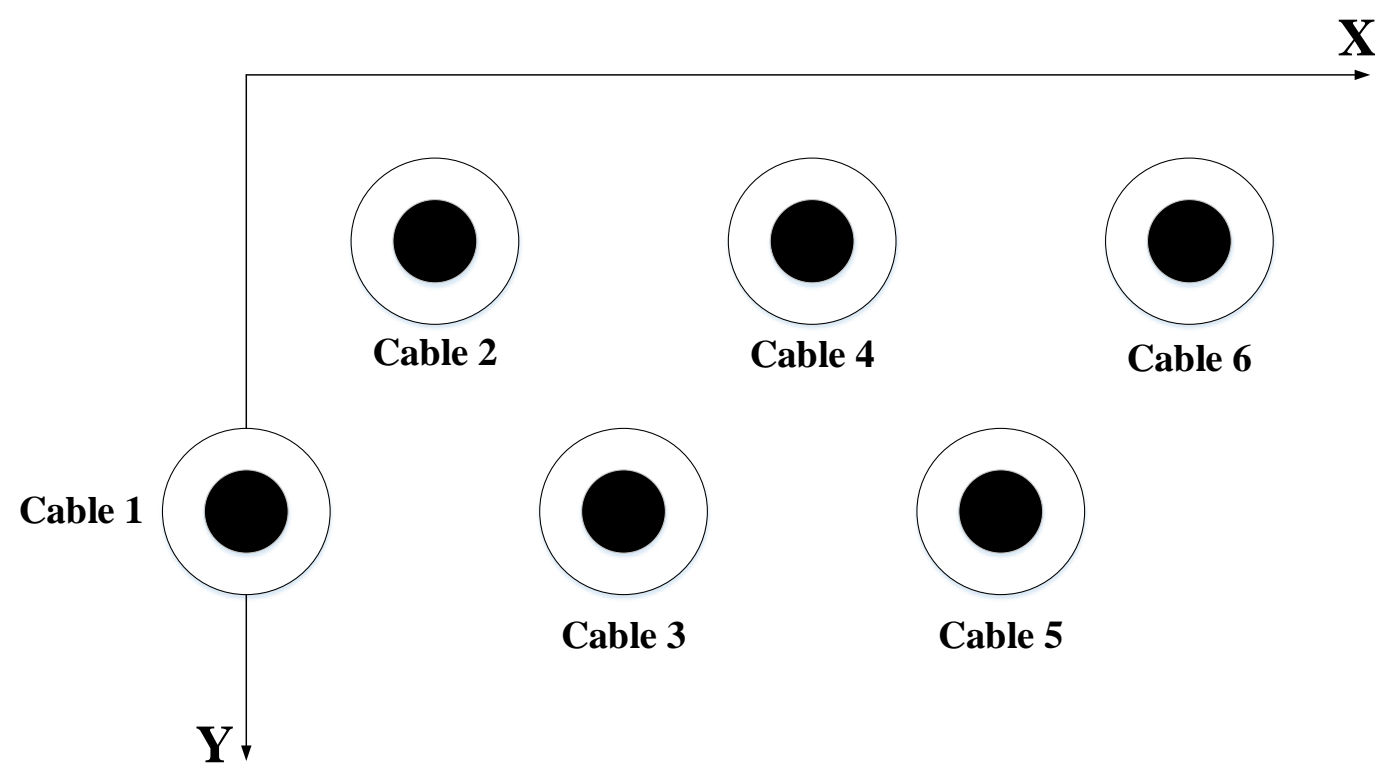

Fig. 5: Cable configuration.

Table 5: Amount of peculiarities phases

\begin{tabular}{ccccccc}
\hline Axis & Cable 1 & Cable 2 & Cable 3 & Cable 4 & Cable 5 & Cable 6 \\
\hline horizontal axis [m] & 0 & 0.11 & 0.22 & 0.33 & 0.44 & 0.55 \\
\hline vertical axis [m] & 1.1985 & 1.0075 & 1.1985 & 1.0075 & 1.1985 & 1.0075 \\
\hline
\end{tabular}

Table 6: Surge arrester current-voltage characteristic

\begin{tabular}{cc}
\hline Current $[\mathrm{A}]$ & Voltage $[\mathbf{k V}]$ \\
\hline $1.0000 \mathrm{e}-4$ & 172.02 \\
$9.9996 \mathrm{e}-4$ & 194.52 \\
$9.9981 \mathrm{e}-3$ & 206.65 \\
$1.0002 \mathrm{e}-1$ & 218.82 \\
$9.9991 \mathrm{e}-1$ & 234.59 \\
$2.5000 \mathrm{e}+2$ & 308.67 \\
$1.0000 \mathrm{e}+3$ & 331.03 \\
$4.9998 \mathrm{e}+3$ & 369.53 \\
$1.0000 \mathrm{e}+4$ & 395.00 \\
$2.0000 \mathrm{e}+4$ & 435.99 \\
\hline
\end{tabular}




\section{EMTP SIMULATION RESULTS AND ANALYSIS}

This section reports the results of the EMTP-RV simulation of the modeled system. We will focus on some of cable characteristics such as cable length, cable core, and sheath resistivity, as well as tower footing resistance. The simulation results have been analyzed and discussed in following sections.

\subsection{Effect of Cable Length on Maximum Overvoltage}

Figure 6 shows forward and backward waves at the end B of the cable when the cable length is $1 \mathrm{~km}$. According to Fig. 6 and equation 2, maximum overvoltage along the cable is $359.5+205=564.5 \mathrm{kV}$ that is equal to the sum of the maximum incoming wave and the maximum reflected wave at the remote end. As mentioned above and according to Fig. 7, maximum overvoltage for a $10 \mathrm{~km}$ cable length is also equal to $292.9+181.2=474.1 \mathrm{kV}$. For a $40 \mathrm{~km}$ cable, according to Fig. 8, maximum overvoltage is equal to $245.8+173.5=419.3 \mathrm{kV}$. These results show that maximum overvoltage strongly depends on cable length. In these figures, the sum of the incoming wave and reflected wave is the main voltage.

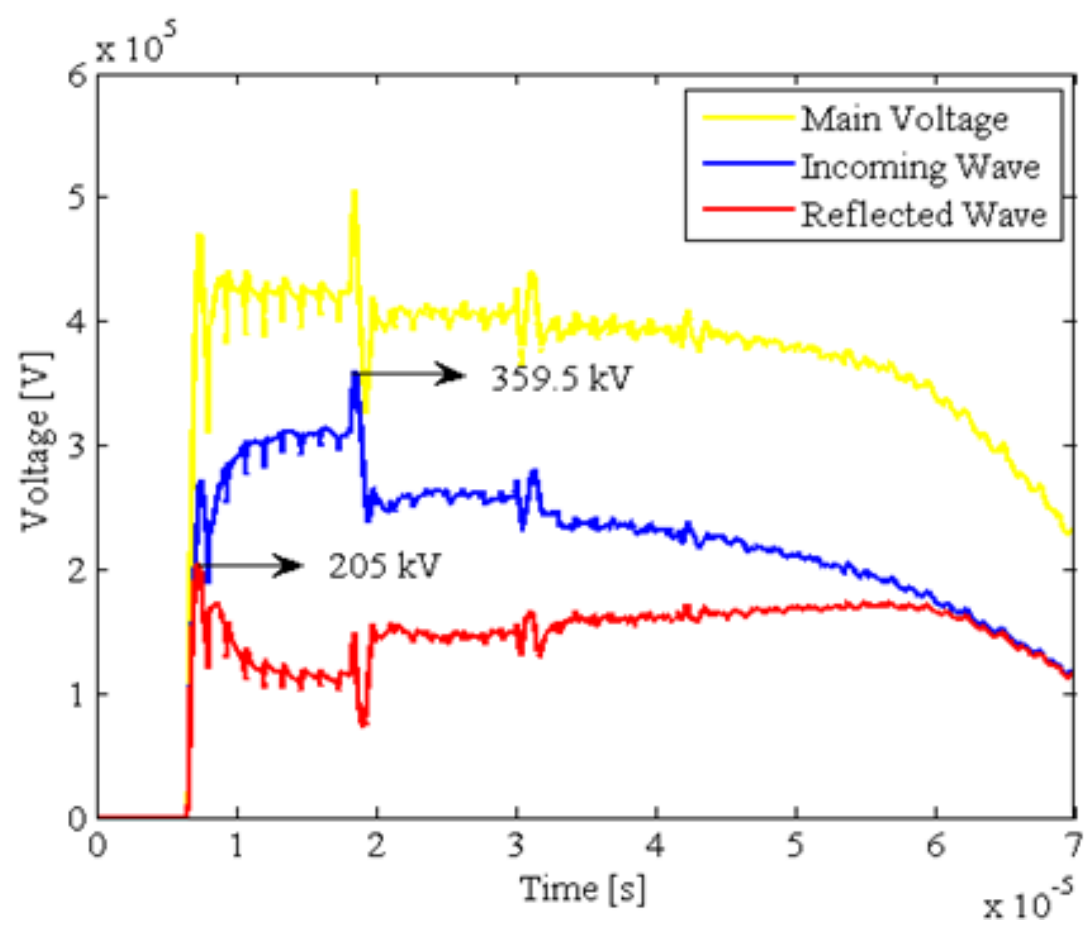

Fig. 6: Forward and backward voltage waves at end B of cable (1 km cable).

Therefore, maximum overvoltage for different lengths is calculated in the range of $500 \mathrm{~m}$ to $65 \mathrm{~km}$ in order to investigate the effect of cable length. Figure 9 shows variations of the maximum overvoltage in the end of the cable line by increasing the length of the cable line.

According to Fig. 9, maximum overvoltage decreases from $570 \mathrm{kV}$ to $387.9 \mathrm{kV}$, when cable line length increases from $500 \mathrm{~m}$ to $65 \mathrm{~km}$, due to the cable attenuation effects. Also, by increasing the cable length, maximum overvoltage gets closer to the surge arresters' protective level. Therefore, according to the above results, maximum overvoltage decreases when cable line length increases. Hence, optimum cable line length should be considered when designing and coordinating the cable insulation because unsuitable 
design can lead to cable insulation failure and network outage. According to simulation results, a lightning strike on top of the second tower in this paper, if cable length more than $31 \mathrm{~km}$, cannot be dangerous for the cable and the cable doesn't need a surge arrester at both ends because maximum voltage along the cable is less than the BIL of the cable.

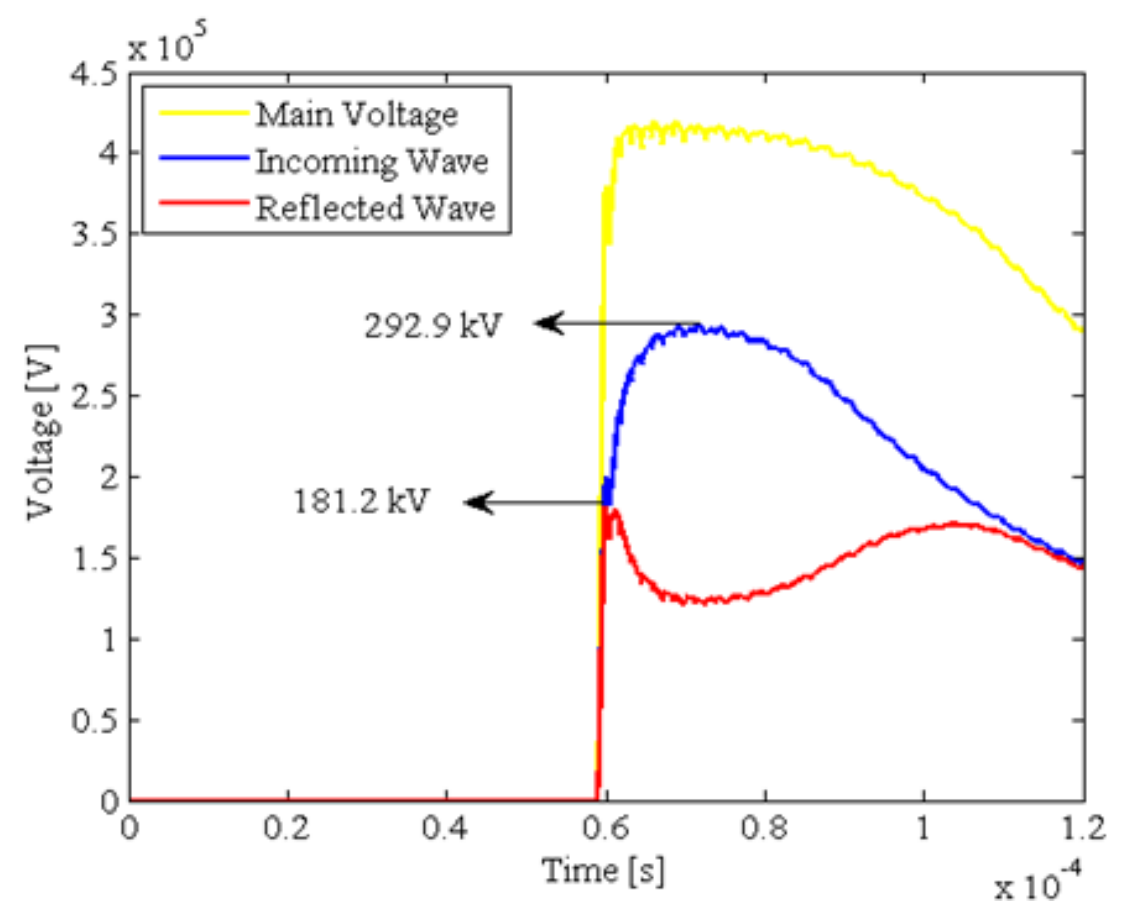

Fig. 7: Forward and backward voltage waves at end B of cable (10 km cable).

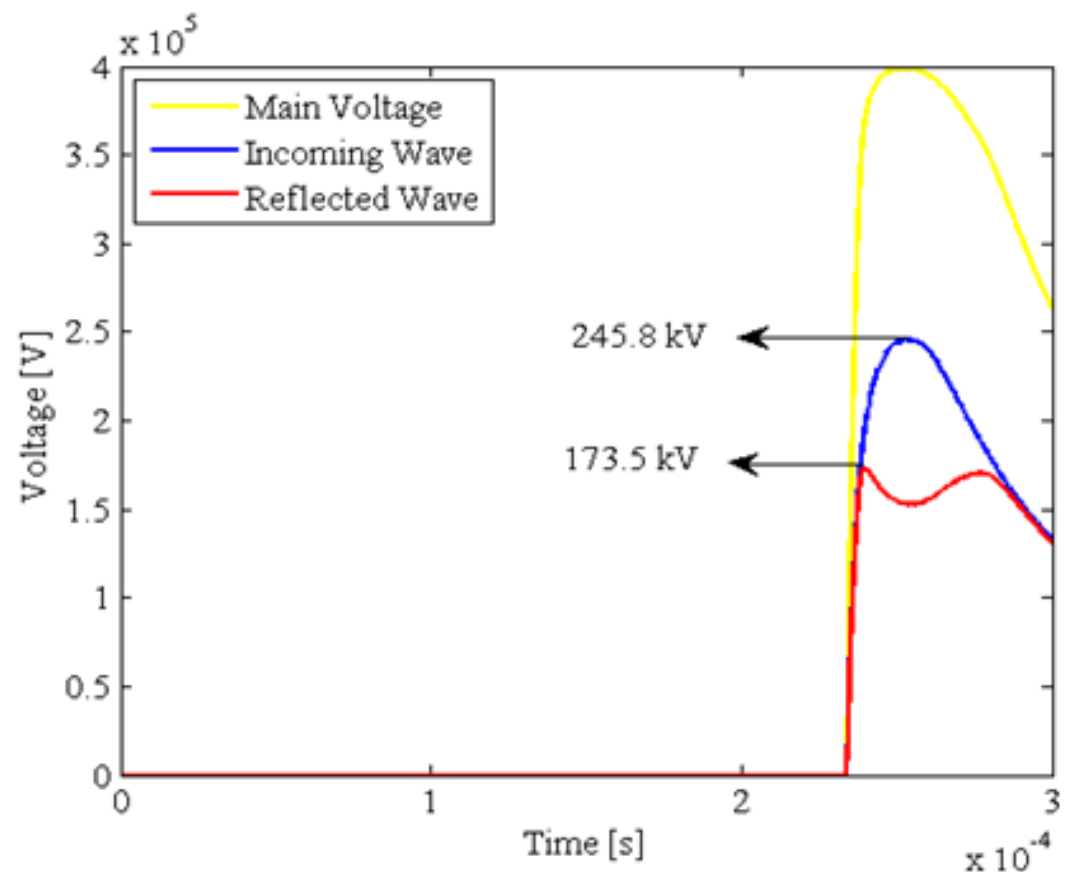

Fig. 8: Forward and backward voltage waves at end B of cable (40 km cable). 


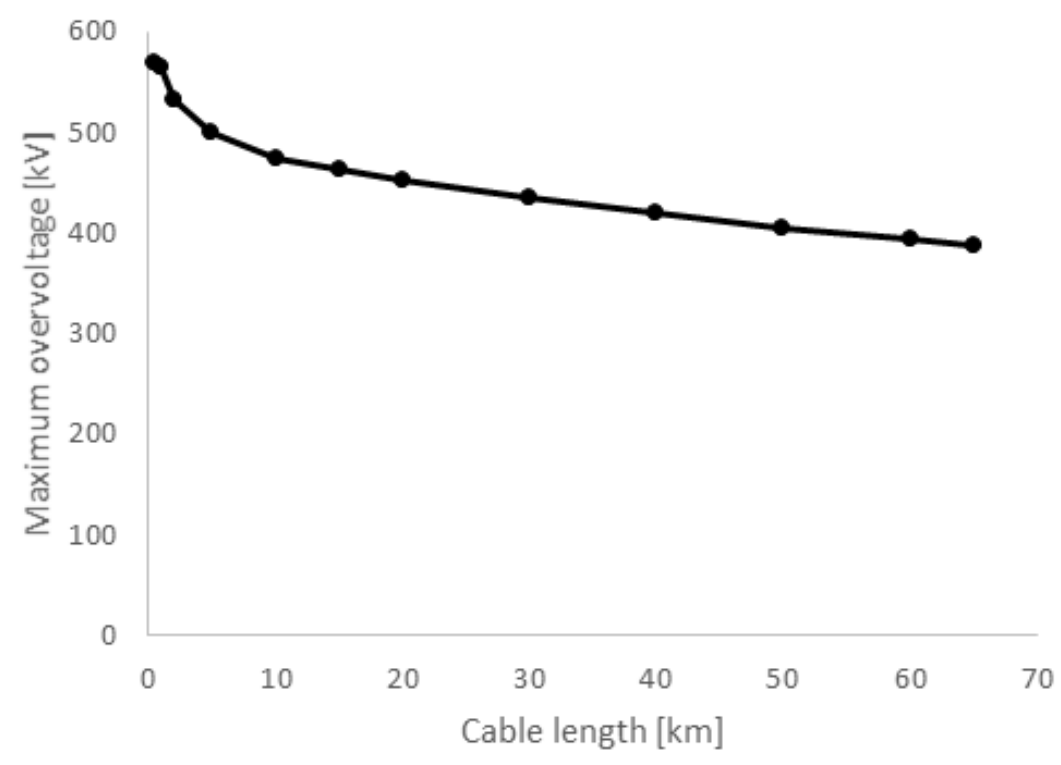

Fig. 9: Maximum overvoltage along the cable as function of cable length.

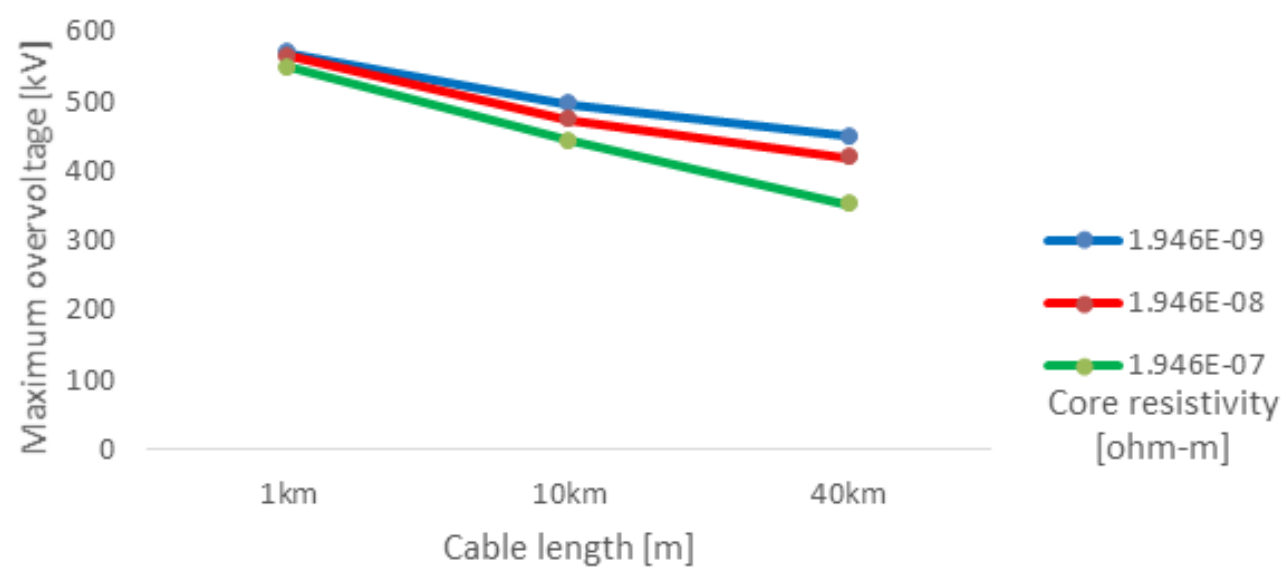

Fig. 10: Maximum overvoltage as function of resistivity of the cable core (1 km, $10 \mathrm{~km}$ and $40 \mathrm{~km}$ cable).

\subsection{Effect of Resistivity of the Cable Sheath on Maximum Overvoltage}

Figure 11 compares maximum overvoltage along the cable with three different values of sheath resistivity for different cable lengths $(1 \mathrm{~km}, 10 \mathrm{~km}$ and $40 \mathrm{~km})$. As seen from the simulation results, maximum overvoltage decreases when sheath resistivity for each length of the cable increases. For example, for every $10 \mathrm{~km}$ length of the cable, maximum overvoltage along the cable for sheath resistivity $2.8 \times 10^{-9} \Omega-\mathrm{m}, 1.678 \times 10^{-8} \Omega-\mathrm{m}$, and $2.1 \times 10^{-6} \Omega$-m are $481.9 \mathrm{kV}, 474.1 \mathrm{kV}$, and $405.7 \mathrm{kV}$, respectively.

\subsection{Effect of Tower Footing Resistance on Maximum Overvoltage}

One of the transmission line parts that can have a significant effect on maximum overvoltage is the tower. During a back flashover, the major part of the strike current flow is transferred toward the ground via the guard wires and towers. The tower footing 
resistance effect on maximum overvoltage is caused by back flashover. Therefore, maximum overvoltage along the cables can be reduced by using a suitable tower footing resistance. Figure 12 shows maximum overvoltage for three different values of tower footing resistance for three different cable lengths $(1 \mathrm{~km}, 10 \mathrm{~km}$ and $40 \mathrm{~km})$. According to this figure, for each length of the cable, maximum overvoltage increases when tower footing resistance increases. Results also show that maximum overvoltage decreases when cable length increases under certain tower footing resistance values. For example, for every $10 \mathrm{~km}$ length of the cable, maximum overvoltage along the cable for each tower footing resistance of $10 \Omega, 30 \Omega$, and $90 \Omega$ is $398.7 \mathrm{kV}, 474.1 \mathrm{kV}$, and $514 \mathrm{kV}$, respectively.

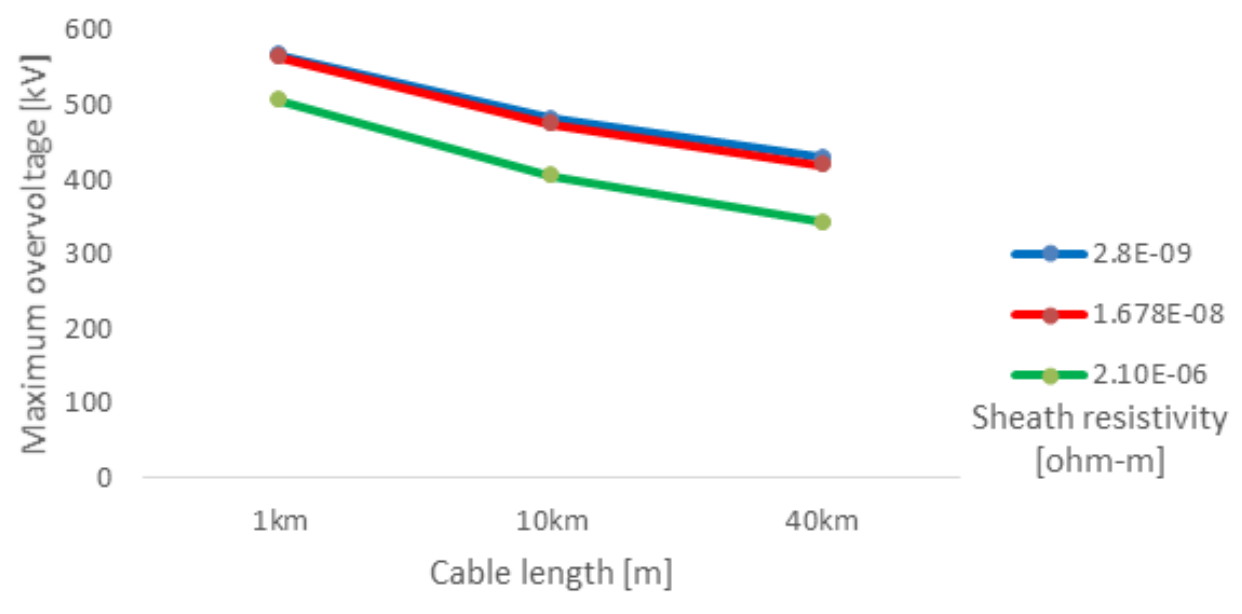

Fig. 11: Maximum overvoltage as function of resistivity of the cable sheath (1 km, $10 \mathrm{~km}$ and $40 \mathrm{~km}$ cable).

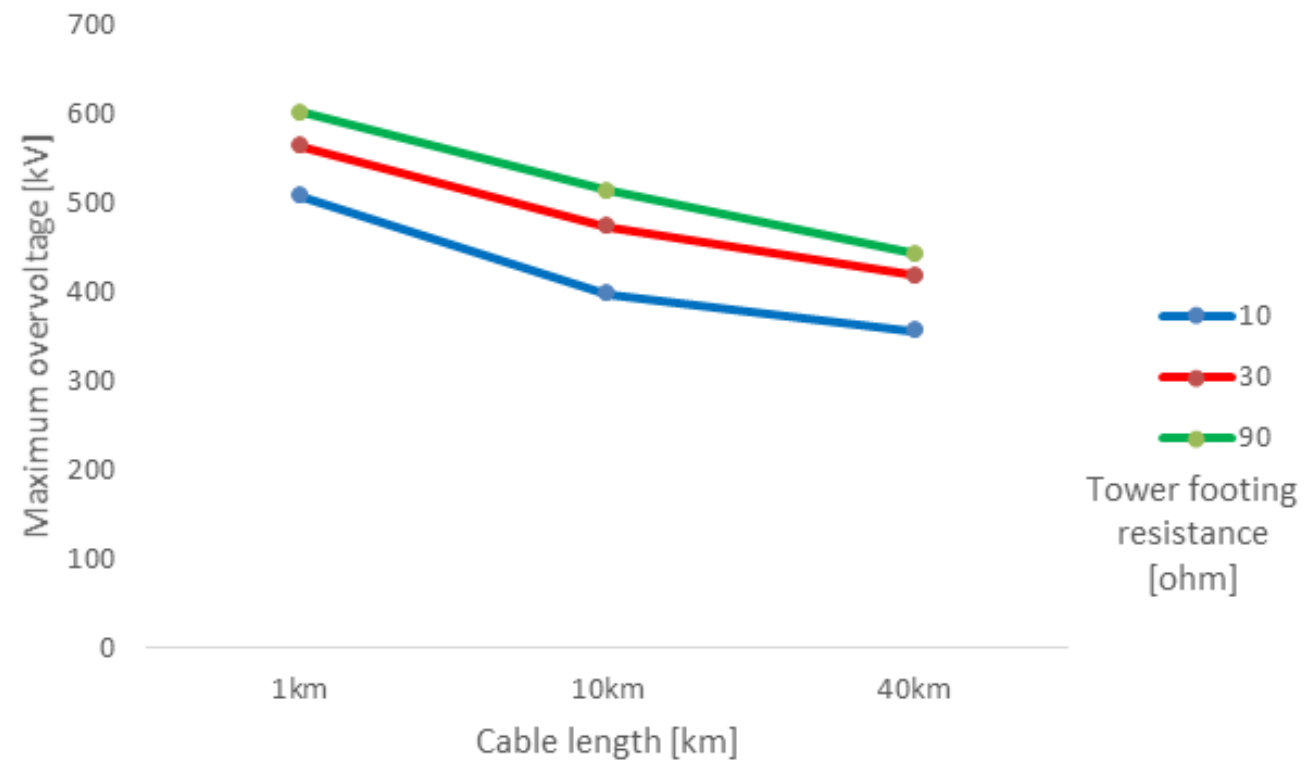

Fig. 12: Maximum overvoltage as function of tower footing resistance

(1 km, $10 \mathrm{~km}$ and $40 \mathrm{~km}$ cable). 


\section{CONCLUSION}

This paper investigates the impact of cable and tower characteristics on maximum lightning overvoltage along a cable in a combined transmission line. Results show that maximum overvoltage along the cable decreases by increasing the length of the cable line. Therefore, increasing cable line length can be a way of protecting cable lines against transient overvoltages. Generally, maximum overvoltage along the cable decreases when cable core resistivity and cable sheath resistivity increases. Also, this maximum overvoltage increases by increasing tower footing resistance. In this paper, simulations show that by increasing the cable length, surge arresters are no longer required because maximum overvoltage gets closer to the surge arresters' protective level when the cable length increases and maximum voltage along the cable is less than the BIL of the cable, so the cable can tolerate the overvoltage. With regard to the obtained results, choosing a suitable type of cable and optimum cable line length can be considered effective factors on cable insulation failure, because the maximum overvoltage strictly affects the insulation coordination.

\section{REFERENCES}

[1] Transpower Report. (2005) Comparison of Reliability of a $400 \mathrm{kV}$ Underground Cable with an Overhead Lines for a $200 \mathrm{~km}$ long circuit.

[2] Transpower Report. (2005) Effect of Short Cable Sections on Reliability of a $400 \mathrm{kV}$ Overhead Line.

[3] Henriksen MT, Gustavsen B, Balog G, Baur U. (2005) Maximum Lightning Overvoltage Along a Cable Protected by Surge Arresters. IEEE Transactions on Power Delivery, 20(2):859-866.

[4] Sadeh J, Damchi Y. (2010) Maximum lightning overvoltage location and reliability indices in power system with combined transmission line. In Transmission and Distribution Conference and Exposition: Latin America (T\&D-LA), 2010 IEEE/PES, pp. 212-217, IEEE.

[5] Balog G. (2005) Transient Voltages Affecting Long Cables. report of CIGRE WG B1-05, Technical brochure no. 269 from CIGRE.

[6] IEEE Std C62.82.1-2010 (Revision of IEEE Std 1313.1-1996) IEEE Standard for Insulation Coordination--Definitions, Principles and Rules.

[7] Zhou LM, Boggs SA. (2002) Effect of shielded distribution cables on lightning-induced overvoltages in a distribution system. IEEE Trans, on Power Delivery, 17(2):569-574.

[8] Martinez JA, Gonzalez-Molina F. (2000) Surge Protection of Underground Distribution Cables. IEEE Transactions on Power Delivery, 15(2):756-763.

[9] Hosseini SA, Mirzaie M, Barforoshi T. (2015) Impact of surge arrester number and placement on reliability and lightning overvoltage level in high voltage substations. International Journal of Electrical Power \& Energy Systems, 65:146-158.

[10] Marzinotto M. (2007) Relationship Between Statistical Distributions of Impinging and Stressing Overvoltages in Power Cable Lines. IEEE Lausanne Power Tech, pp. 1911-1916.

[11] Marzinotto M, Mazzetti C, Schiaffino P. (2005) Statistical Approach to the Insulation Coordination of Medium and High Voltage Cable Lines. IEEE Power Tech.

[12] Marti L, Dommel HW. (1997) Calculation of voltage profiles along transmission lines. IEEE Trans, Power Del, 12(2): 993-998.

[13] Miguel C, Ramirez A. (2014) Frequency-domain computation of maximum lightning overvoltage along a cable protected by surge arresters. North American Power Symposium (NAPS), IEEE.

[14] Oramus P, Florkowski M. (2014) Simulations of lightning overvoltages in HV electric power system for various surge arresters and transmission lines models. Przegląd Elektrotechniczny, 90(10):137-140. 
[15] IEEE Modeling and Analysis of System Transients Working Group. (1996) Modeling guidelines for fast transient. IEEE Trans, Power Del, 11(1): 493-506.

[16] Ametani A, Kawamura T. (2005) A method of a lightning surge analysis recommended in Japan using EMTP. IEEE Trans, Power Del, 20(2, pt. 1):867-875. 